\title{
Morphological detection and quantification of lipoprotein(a) deposition in atheromatous lesions of human aorta and coronary arteries
}

\author{
Axel Niendorf ${ }^{1}$, Matthias Rath ${ }^{2}$, Katrin Wolf ${ }^{1}$, Susanne Peters ${ }^{1}$, Hartmut Arps ${ }^{1}$, \\ Ulrike Beisiegel $^{2}$, and Manfred Dietel ${ }^{1}$ \\ ${ }^{1}$ Institut für Pathologie und ${ }^{2}$ Medizinische Kern- und Poliklinik Universitäts-Krankenhaus Eppendorf, Universität Hamburg, \\ Martinistrasse 52, W-2000 Hamburg 20, Federal Republic of Germany \\ Virchows Archiv A Pathol Anat (1990) 417:105-111
}

In the paper by A. Niendorf et al. (Virchows Archiv A Pathol Anat 1990, 417:105-111), it was stated that Lp(a) was detected by Blumberg et al. and Berg. It is well established that Lp(a) was discovered by Berg and the correct quotation to the original report is: Berg K. (1963), A new serum type system in man - The Lp system. Acta path microbiol Scand 59:369-382. The authors regret this mistake. 